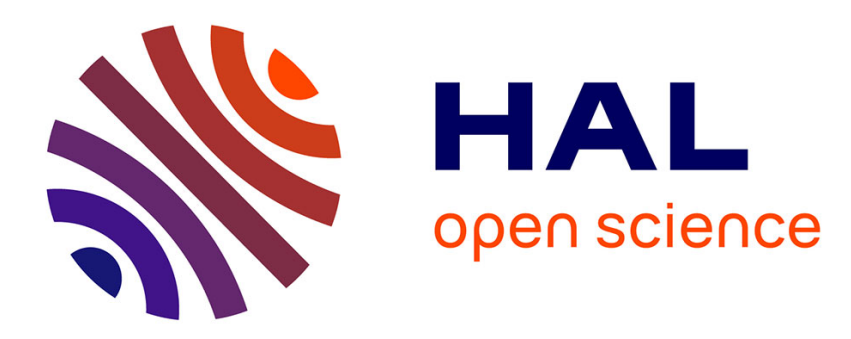

\title{
Employability of young graduates in Europe
}

Christelle Garrouste, Margarida Rodrigues

\section{To cite this version:}

Christelle Garrouste, Margarida Rodrigues. Employability of young graduates in Europe. International Journal of Manpower, 2014, 35 (4), pp.425-447. 10.1108/IJM-05-2013-0106 . halshs-01056703

\section{HAL Id: halshs-01056703 \\ https://shs.hal.science/halshs-01056703}

Submitted on 20 Aug 2014

HAL is a multi-disciplinary open access archive for the deposit and dissemination of scientific research documents, whether they are published or not. The documents may come from teaching and research institutions in France or abroad, or from public or private research centers.
L'archive ouverte pluridisciplinaire HAL, est destinée au dépôt et à la diffusion de documents scientifiques de niveau recherche, publiés ou non, émanant des établissements d'enseignement et de recherche français ou étrangers, des laboratoires publics ou privés. 


\title{
Employability of young graduates in Europe*
}

\author{
Christelle GARROUSTE ${ }^{\dagger}$ \\ (Department of Economics, Laboratoire d'Economie d'Orléans, Orléans, France) \\ Margarida RODRIGUES \\ (JRC-IPSC, Econometrics and Applied Statistics Unit, Ispra, Italy)
}

\begin{abstract}
Structured Abstract
Purpose - This paper aims at measuring the potential role of the field of education and the fact of having worked during studies on the employability of the higher educated (ISCED 5-6) cohort targeted by the ET2020 graduates' employability benchmark.

Design/methodology/approach - Using the same data source as the benchmark (i.e., the annual LFS microdata from 2004 to 2010), and exploring the additional transition questions collected in the LFS 2009 ad-hoc module, we define and test four hypotheses using a probit approach on each EU country. Findings - The degree plays a significant role in the employability of young graduates across countries and time. In terms of probability of employment, the leading field is Health and welfare. In terms of type of contracts, the leading fields are Social sciences and Engineering. Moreover, what labour markets seem to value the most is the capacity of higher educated students to combine high level studies and work, i.e. a high workload capacity and intellectual flexibility.

Practical implications - Reaching the new European target of a minimum of $82 \%$ of employment of young graduates will require countries to invest wisely in the most "employable" fields of education. This analysis will help policy makers in their future orientations towards that target.

Originality/value - The originality of this work lies in its exploration of the exact same extraction of microdata used for the computation of the ET2020 Benchmark indictor and in its immediate political implications for the monitoring of this benchmark.
\end{abstract}

Keywords: Employability benchmark, Higher education, Degree fields, Work experience, Contracts

Article Classification: Research

\footnotetext{
${ }^{*}$ Acknowledgments: This paper uses microdata from the Labour Force Survey (LFS) for the years 2004 to 2010, extracted September 14, 2011, and microdata of the LFS 2009 ad-hoc module. The authors would like to thank two anonymous reviewers for their valuable suggestions. All remaining errors are the sole responsibility of the authors.

† Corresponding Author : christelle.garrouste@univ-orleans.fr
} 


\section{Introduction}

In May 2012, the European Council adopted a new European target on the employability of students (European council, 2012). This new benchmark complements a set of joint targets in education and training that should be reached by 2020 (ET2020): reducing early school leaving; increasing the share of higher education graduates; increasing participation in early childhood education; getting more adults to participate in lifelong learning; and increasing learning mobility. These ET2020 benchmark targets were adopted to raise awareness in all Member States about the key role played by education and training in the 'Europe 2020 strategy' to exit the recession and establish the foundations for future knowledgebased growth and social cohesion. They aim at stimulating and guiding reforms and measures targeting educational systems (European Commission, 2011).

The employability benchmark monitors the success rate of young people with different education levels in the labour market in the three years after graduation. In particular, the benchmark is defined as the share of young people employed, among the 20-34 years old, who graduated from upper secondary school or above, no more than three years before, and are not currently in education or training (Garrouste, 2011).

This paper aims at presenting some findings from a broad project analyzing the determinants of the probability of being employed and the nature of the employment of the full cohort (i.e. ISCED 3-6) targeted by this new ET2020 benchmark. The results reported in this paper cover only the tertiary educated cohort (i.e. ISCED 5-6).

In this paper, we are mainly interested in understanding how the field of the tertiary degree and working experience during studies contribute to i) the probability of being employed; and, among those employed, to ii) the probability of having a permanent contract, and iii) the probability of having a full-time contract. The choice of these three outcomes is motivated by a political mandate from the European Commission and supported by empirical evidences of the role played by the success or failure in the transition from education to work in the future career. Indeed, unemployment spells early in the working life may harm long term career 
paths and earning prospects (Schmelzer, 2011), both due to skills' depreciation and to the increasing difficulty to re-enter the labor market. Young individuals are also more likely to accept temporary or part-time positions for which they are overqualified. This mismatch can have damaging impacts on lifelong earnings and career paths (Robst, 2007).

By exploring the contribution of the field of the degree and of working experience during studies, we aim at understanding better which fields and which types of skills, theoretical or applied, the employers of young graduates look after. This analysis can hopefully contribute to the design of policies and curricula in higher education.

The study is conducted using two data sources. First, the same data source as the one used to compute the benchmark, i.e. the annual LFS microdata, from 2004 to 2010. Then the 2009 LFS ad-hoc module on transitions from school to work, where information on work experience during studies is available.

The paper starts with a discussion of the concept of employability as used in the ET2020 benchmark indicator and the hypotheses this paper aims at testing. It proceeds with the presentation of the data and the econometric approach. The results from the estimation of the probability of being employed 1 to 3 years after graduation are reported and discussed in section 3 , followed by the results of the analysis of the type of contract, in section 4 . The paper concludes in section 5 with a synthesis of the findings and suggestions for further research.

\section{Measuring employability: the European Council's approach}

In this section, we summarize the conceptual background of the ET2020 graduates' employability benchmark and give a short presentation of the indicator. For further details on this point, we refer the reader to Garrouste and Rodrigues' (2012) report.

The difficulty in applying a straightforward definition of employability has been recognized by various studies (Arjona Peres et al., 2010a). McQuaid and Lindsay (2005) highlight the existence of two alternative perspectives in the employability debate. One focuses only on the individual's characteristics and skills, referring to the individual's potential to obtain a job. The other perspective takes 
into account external factors (e.g. labour market institutions, socio-economic status) that influence a person's probability of getting into a job, of moving between jobs or of improving his/her job. De Grip et al. (2004) call these factors 'effectuation conditions', i.e. the conditions under which workers can effectuate their employability. In addition, the literature also considers the aspects of the time lag between leaving education and employment (e.g., Boateng et al., 2011), the degree of skills match between one's educational background and his/her occupation, and the type of contractual arrangement (full-time vs. part-time; permanent vs. temporary) (Arjona Peres et al., 2010a).

In view of all these dimensions, and given the fact that the interest of the European Commission was to identify ways in which education and training policies impact and can further enhance employability, the transversal definition given by Cedefop (2008) was finally retained as conceptual reference: "Employability is the combination of factors which enable individuals to progress towards or get into employment, to stay in employment and to progress during their career" (European Commission, 2011).

Hence, the Commission agreed to view education's support for employability in three distinct phases: (i) "Preparation for employment"; (ii) "Transition from education to employment"; and (iii) "Stay in employment and progress in career". Of these three phases, two were already monitored by an extensive framework. The first phase is covered by four of the five benchmarks under the ET2020 and the third phase is covered by the fifth ET2020 benchmark on adult participation in lifelong learning. The phase relating to the "transition from education to work" was not yet addressed and became therefore the phase upon which the new benchmark on the employability of young graduates focused (Arjona Peres et al., 2010a, 2010b; Garrouste, 2011; European Council, 2012). Beyond the phase of implementation, definitions of employability can target immediate employment, immediate employability, or sustainable employability (Watts, 2006). Due to data and comparability constraints, it was decided that the proposed benchmark indicator on the employability of graduates from education and training shall focus on immediate employment. 
In the end, the following definition was adopted by the European Council in May 2012: "By 2020, the share of employed graduates (20-34 year olds) having left education and training no more than three years before the reference year should be at least 82\%" [1] (European Council, 2012). This target is an EU27-average target, not a country-level target.

Figure 1 presents the trend series data of this new European benchmark. From this figure we see clearly that the level of educational attainment plays a positive role in the employability of young graduates. This comparative advantage of the higher educated in the labour market is true for each EU country and over time, and remains constant after controlling for individual characteristics and labour market conditions (Garrouste and Rodrigues, 2012).

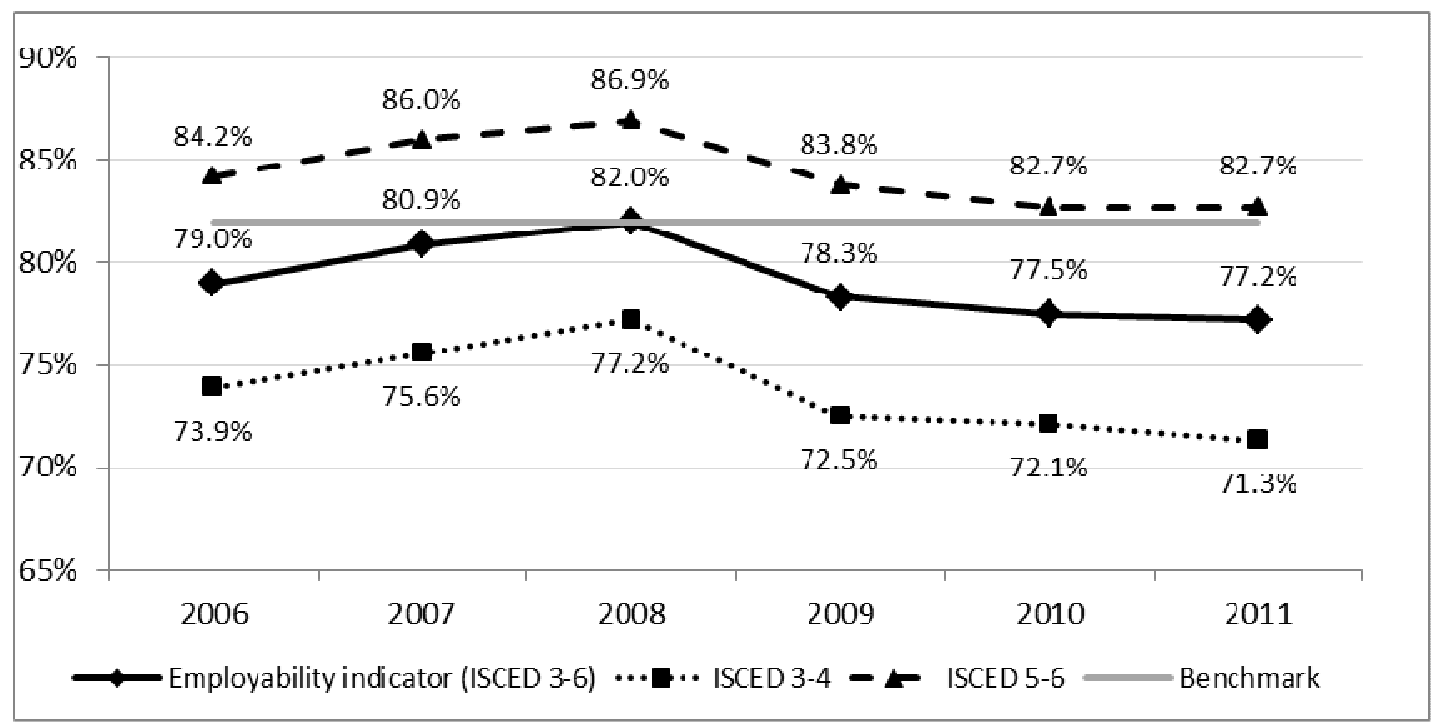

Figure 1. Employability benchmark by level of education, 2006-2011 Source : Eurostat, EU LFS microdata (extraction date : June 13, 2012)

In its conclusions on the benchmark proposal on employability of graduates, the European Council invited the Member States and the Commission to "examine how to incorporate more practical elements into education and training, for instance through applied learning or dual education, as a way of enhancing the employability of graduates" (European Council, 2012, p.9). 
This paper aims at providing a first insight into this request by estimating how much the higher educated cohort's employability in the three years following graduation has been affected by the field of the degree, and by the fact of having worked during studies. More concretely, this paper tests four hypotheses derived from the European Commission's views and expectations on the topic:

$\checkmark \quad$ Hypothesis 1: Degrees in applied fields are more demanded by national labour markets;

Hypothesis 2: A work experience during studies constitutes an asset for young graduates;

$\checkmark \quad$ Hypothesis 3: The nature of the contracts at the beginning of the career of a young graduate is related to the field of his degree;

$\checkmark \quad$ Hypothesis 4: The nature of the contracts of a young graduate is affected by the work experience acquired during studies.

The first two hypotheses mainly derive from the report by Cedefop (2012) on a forecast of the supply and demand for skills in Europe, in which it is stated that highly-qualified technicians and associate professionals are becoming increasingly important in the modern economy. In the same report, it is explained that there are increasing numbers of students opting for tertiary-level vocational qualifications in an attempt to better match the changes in the skills demanded. The literature in education economics corroborates this descriptive statistical evidence. For instance, in Ireland, Kelly et al. (2010) find that among all fields of tertiary degrees, the ones associated to higher returns are Medecine and Veterinary, Education, Engineering and Architecture, Science, Computers and IT. Overall, the skills producing the highest returns are technical skills. In an analysis of the employability by type of college major in the U.S., Carnevale et al. (2012) demonstrate that unemployment rates are generally higher in non-technical majors, such as the Arts, Humanities and Liberal Arts, and Social Sciences.

The second hypothesis refers to the ongoing debate on the effect of work during studies on students' performance and labour market returns. On the one 
hand, there is empirical evidence of a negative effect of part-time work on students' performance (e.g., Lindsay and Paton-Saltzburg, 1993; Leonard, 1995; Dustmann et al., 1996; McVicar and McKee, 2002) that may be inflated by the presence of a potential selection bias into work during studies (Ehrenberg and Sherman, 1985). On the other hand, there is also empirical evidence that part-time employment during studies enables students to develop employability skills that are praised during recruitment interviews (e.g., Harvey et al., 1998; Watts and Pickering, 2000; Curtis and Shani, 2002; Neill et al., 2004). The most employable skills acquired through work during studies are team-working, being given responsibility, and collaborative learning (Crebert et al., 2004; Shah et al., 2004).

Our third and fourth hypotheses build upon the literature on the transition from school to work. The transition to a permanent employment has proven to be a milestone for the building of an independent household (OECD, 2000). Although the transition from school to work is only the initial step into the labour market, many studies have emphasized that a smooth transition may minimize experiences of unemployment and inactivity, as well as accelerate the speed of convergence to a permanent employment (e.g., Eckstein and Wolpin, 1995; Korpi et al., 2003; Wolbers, 2007; Schmelzer, 2011). In that context, a smooth transition refers to a transition with no, or few, instable or precarious jobs. Job instability is associated to temporary contracts and job precarity to low paid contracts, such as part-time contracts. The focus on the impact of the field of the degree, and of work during studies, on the probability of having a permanent and full-time contract aims at understanding the nature of graduates' employability and at assessing the capacity of educational institutions to influence a smooth transition.

\section{Data and estimation approaches}

The benchmark indicator on graduates' employability from education and training was jointly computed by the Center for Research on Education and Lifelong Learning (CRELL) and Eurostat (Garrouste, 2011, Boateng et al., 2011) using the microdata from the annual LFS between 2004 and 2010, as extracted in September 14, 2011. All estimates presented in this paper are computed using data from the 
same extraction date, except for the analysis of the role of the combination of work and studies, which makes use of the anonymized microdata from the LFS ad-hoc module of 2009 on the transition from school to work.

For each year between 2004 and 2010, we focus on the respondents aged 20 to 34 years old, who graduated 1 to 3 years before the time of the survey from tertiary education (i.e. at ISCED 5 or 6 ) and who were not enrolled in any further education or training activity in the four weeks preceding the interview. As well acknowledged by the European Commission in its preparation of the Benchmark indicator, many employability factors lay beyond the scope of education and training policies. At the individual level, socio-economic determinants and personal attributes play an important role; while at the macro level, labour market regulations, structure of the economy and the overall economic situation constitute important employability conditions (Arjona et al., 2010a and 2010b; European Commission, 2011). Although it is impossible to control for all these factors, we attempt to better isolate the effect of the economic crisis on our estimates by generating two pooled sub-samples according to the year of the survey: the precrisis sample (2004-2007) and the crisis sample (2008-2010).

Figure 2 plots for each EU country the change in employment rate of the higher educated benchmark cohort between the pre-crisis period (2004-2007) and the crisis period (2008-2010). In most countries, the young graduates from higher education have suffered a lower employment rate since the beginning of the crisis compared to their situation before the crisis. This decrease was particularly strong for the Irish (-7.1 percentage points), the Spanish (-5.7 p.p.), the Greek (-5.1 p.p.) and the British (-3.7 p.p.). Still, in ten countries they have seen their employability increase, with the highest increase in Poland (+2.9 p.p.), Sweden $(+2.6$ p.p.), France (+2.1 p.p.) and Germany (+1.9 p.p.). 


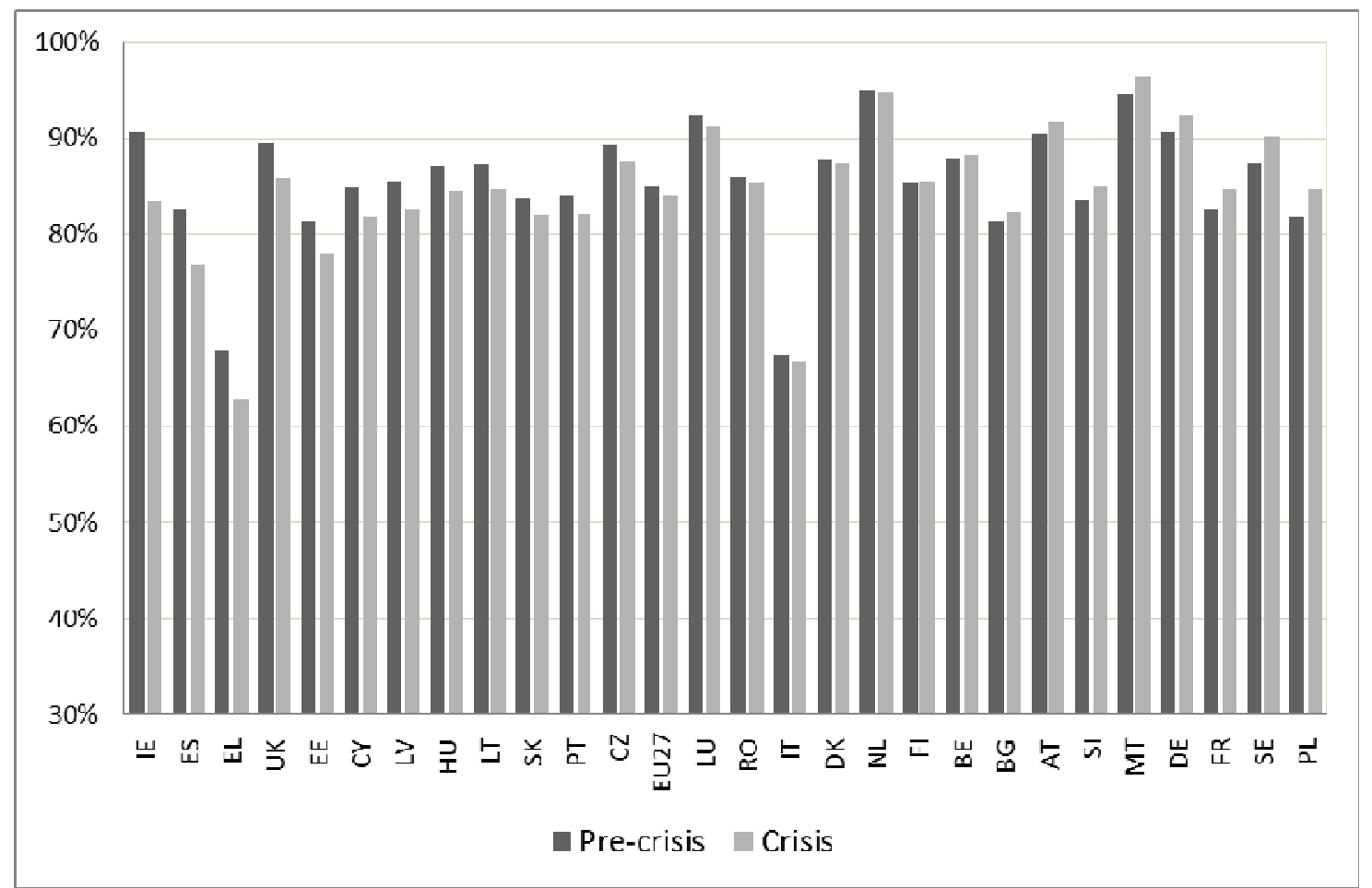

Figure 2. Averaged employment rate of the benchmark cohort that graduated from higher education, by country and by time period pre-crisis (2004-2007) and crisis (2008-2010) Source: Authors' estimates using the core LFS 2004-2010.

Note: Countries are ordered by increasing percentage points difference between the two periods.

In order to assess the validity of Hypothesis 1, we test at country-level the specific role played by each type of degree field in the probability of being employed soon after graduation and how much the economic crisis has affected this role. Specifically, we estimate for each time period (i.e. pre-crisis and crisis periods) and for each country the role played by a set of individual demographic and educational characteristics (adjusting for unobserved institutional factors) on the probability of being employed. The observed individual characteristics are captured by a vector $X_{i}$ including the age of the respondent (in continuous terms comprised between 20 and 34), the age squared, gender, the time since graduation (1, 2 or 3 years before) and one dummy variable for each field of degree at a time. The latter serves at assessing whether the specific field of degree considered increases or decreases the probability of being employed in comparison to all other fields. We also add fixed effects for the following variables: year of the survey, $\alpha_{y}$ (where the reference category is 2004 for the pre-crisis sample; and 2008 for the crisis period), the region 
of residence, $\gamma_{r}$, and an interaction term between year and region, $\alpha_{y} \gamma_{r}$, as a proxy for unobserved labour market characteristics. The analysis is conducted using a probit approach:

$\operatorname{Pr}\left(Y_{i}=1 \mid X_{i}\right)=\Phi\left(X_{i}^{\prime} \beta_{i}+\alpha_{y}+\gamma_{r}+\alpha_{y} \gamma_{r}\right)$

where $Y$ is our outcome dichotomous variable, $i$ is the index for individuals, $r$ the index for region and $y$ the index for years. Pr denotes probability, and $\Phi$ is the Cumulative Distribution Function (CDF) of the standard normal distribution. The parameters $\beta$ are estimated by maximum likelihood, applying a weighting factor equal to the inverse of the individual inclusion probabilities. We choose the probit approach rather than the logit approach because the actual event is more a proportion than a binary outcome (Wooldridge, 2010). To ensure representativeness of our estimates, we apply a weighting factor equal to the inverse of the individual inclusion probabilities. In our sample, the most represented fields of diploma are Engineering, Manufacturing and Construction; Humanities, Languages and Arts; Social Sciences, Business and Law; and Teacher Training and Education Sciences (see Table A.1 for details).

Second, to study Hypothesis 2, we complement our analysis exploiting the microdata from the 2009 LFS ad-hoc module on the transition from education to work to test more specifically the role played by the acquisition of a professional experience during studies, using the same model specifications as before. This is done by including in the vector $X_{i}$ a variable related with the work experience during studies (workeduc). The year fixed effects are removed since the ad-hoc module was collected only in 2009. This second model yields:

$$
\operatorname{Pr}\left(Y_{i}=1 \mid X_{i}\right)=\Phi\left(X_{i}^{\prime} \beta_{i}+\alpha_{r}\right)
$$


where $i$ is the index for individuals, $r$ the index for regions, and $X_{i}$ the vector of individual characteristics: age, age squared, gender, time since graduation, dummies for the field of the degree and our variable of interest, work during studies.

We measure the professional experience acquired during studies in two different ways using the categorical variable WORKEDUC collected in the LFS 2009 ad-hoc module:

\section{WORKEDUC - Work during studies in formal education:}

0. did not work or worked less than 1 month per year

1. worked (only) as part of the educational programme

2. $\quad$ worked while studying but outside educational programmes

3. worked (only) during an interruption of studies

4. $\quad$ worked as a combination of (1) and (2)

5. $\quad$ worked as a combination of (1) and (3)

6. $\quad$ worked as a combination of (2) and (3)

7. $\quad$ worked as a combination of (1), (2) and (3)

In a first step, we generate a dummy variable, workedu, taking value one if the respondent answered any of the alternative options (1) to (7) and zero if he answered category 0 . The estimation of the role played by any work experience during tertiary-level studies aims at informing policy makers about potential changes, since the beginning of the crisis, in the needs of national labour markets for vocational vs. theoretical tertiary-level skills. Although $56 \%$ of our European sample declares having worked during studies (Table A.1), we observe a very strong heterogeneity across countries. Austria, Denmark, Netherlands, France and Sweden report over $75 \%$ of work activities during studies; and Spain, Portugal, Hungary and Romania report less than $40 \%$.

In a second step, we make use of the full range of answers provided by the variable WORKEDUC and estimate the effect of each type of work experience in comparison to the fact of reporting no work experience during studies (using the category 0 "did not work or worked less than 1 month per year" as reference category). The specific information on the type of experience acquired during 
studies is essential for policy makers to understand whether it is worth investing in work experience as part of the curriculum (in form of apprenticeships or internships) or if the markets value similarly any type of work experience. Among the $56 \%$ of European graduates that reported having worked during their studies, only $21 \%$ did it as part of their educational programme while $59 \%$ did it outside the programme. The only countries reporting at least $40 \%$ of graduates having worked as part of their educational programme are Italy, Luxemburg and Greece. At the other end of the distribution, they are less than $10 \%$ in the Netherlands, Spain, Portugal, Latvia, Sweden and Slovenia. Further descriptive statistics of the estimated pooled samples for models (1) and (2) are presented in Table A.1.

Hypothesis 3 and Hypothesis 4 deal with the role played by the field of the degree and the work experience during studies on, respectively, the length and the type of contract of a young graduate. These are tested using models (1) and (2), which are re-estimated considering only young graduates that are currently employed and replacing the binary outcome by (i) the probability of being employed at a permanent position (vs. a temporary contract); and (ii) the probability of working full-time (vs. part-time).

\section{Employment probability of young graduates}

This section reports the results from models (1) and (2) estimating the probability of being employed 1 to 3 years after graduation at tertiary level, respectively focusing on the effect of the field of the degree (Hypothesis 1) and the working experience during studies (Hypothesis 2).

\subsection{Hypothesis 1 - Degrees in applied fields are more demanded by national labour markets}

Table 1 summarizes the probit estimation results from Model (1), listing the countries for which a field of graduation had a statistically significant coefficient (at least at the $\mathrm{p}<0.05$ level), ceteris paribus. It reveals that the field of the completed degree has a statistically significant impact on the probability of being employed in all European countries, except Lithuania and Luxembourg during the pre-crisis 
period, and Luxembourg during the crisis period. Furthermore, across time and countries, the least employable diplomas are the ones in the field of Humanities, Languages and Arts; and the most employable the ones in Health and Welfare. This global trend validates our Hypothesis 1 of a sustainable advantage of more applied fields compared to theoretical and general programmes.

\section{[Table 1 about here]}

Beyond that global trend, our analysis points at specific fields for which some countries could gain either in investing more or in reducing their intakes. Such fields are identifiable looking at the underscored countries in Table 1. If a specific field reveals a statistically significant comparative advantage in the probability of being employed in a certain country, both during the pre-crisis period and the crisis period, then the concerned country would probably win in increasing the number of graduates from that field. On the other hand, if a field reveals a sustainable disadvantage over time in a certain country, this could be the sign of an overproduction of graduates from that field. The country would therefore gain from reducing the intakes into that field until the supply size meets again the demand size. For instance, Italy may gain from increasing the number of its graduates from the fields of Computer Science; Engineering, Manufacturing and Construction; Health and Welfare and from reducing the intakes into the fields of Humanities, Languages and Arts; and Social Sciences, Business and Law.

\subsection{Hypothesis 2 - A work experience during studies constitutes an asset for young graduates}

The results of the estimation of model (2), which exploits the specific question of the ad-hoc module of the LFS 2009 on a work experience during studies, are synthesized in Table 2 (column 1). From Table 2 we see that the introduction of the dummy variable workedu in model (1) reveals a positive and statistically significant impact of work during studies on the probability of being employed in a large 
number of European countries (Bulgaria, Czech Republic, Greece, Ireland, Netherlands, Poland, Romania and Italy).

When replacing the dummy variable workedu by the categorical variable WORKEDUC, we find that, ceteris paribus, the only country in which work as part of the curriculum gives a concrete advantage in the probability of being employed soon after graduation, compared to no work experience at all, is Ireland. On the other hand, work while studying but outside educational programmes is recognized as a plus in Denmark, Greece, Ireland, Italy, Lithuania, Netherlands, Portugal and Romania. The combination of work activities outside and as part of the educational programmes gives an advantage to newly graduates in Bulgaria, Greece and Italy. Moreover, Poland also recognizes the combination of work while studying but outside the programmes with work during an interruption of studies. The opposite is true in Austria, where the estimated coefficient of this specific combination presents a statistically significant negative sign. Finally, France is the only country where a work experience accumulated only during an interruption of studies is considered as negative for obtaining an employment.

Globally, this analysis shows that having worked while studying but outside educational programmes, or having combined work activities outside and as part of the educational programmes, make a statistically significant positive difference on the European markets, as compared to no work activity at all, ceteris paribus. Hence, once again, the educational programme alone does not make the difference for the employability of young graduates, even if the programme includes a practical work experience. What the labour markets seem to value the most is the capacity of a higher educated student to cumulate skills related to high level studies and work experience. This result is consistent with the human capital literature according to which a graduate's employability increases with the pertinence of the degree's major discipline, the level of the grades and the fact of having worked during studies outside the curriculum (Marshall, 1985).

[Table 2 about here] 


\section{Nature of contracts of employed young graduates}

After having estimated the impact of education on the employment probability of young graduates, we now focus our interest on young people employed 1, 2 or 3 years after their graduation. First of all, we look at their probability to be employed with a permanent contract (vs. a temporary contract). Then we look at the full-time (vs. part-time) nature of their employment (i.e. model (1) - Hypothesis 3). The aim of this analysis is to identify potential fields of diplomas that tend to enhance/diminish the chances of getting a permanent position or a full-time contract early in the career. Moreover, we are interested in identifying which type of work experience during studies improves the most the conditions of employment of young graduates, again in terms of duration and type of contract (i.e. model (2) - Hypothesis 4).

\subsection{Hypothesis 3 - The nature of contracts at the beginning of the career of a young graduate is related to the field of his degree}

Across European countries, among the young graduates that are employed, the probability of working full-time and the probability of having a permanent contract have remained stable across Europe between the pre-crisis period and the crisis period (Table A.1). Tables 3 and 4 synthesize the effect of each field of studies ceteris paribus, respectively on the probability of having a permanent contract and on the probability of working full-time.

Overall, the economic crisis did not change significantly the relationship between specific fields of degree and the nature of the employment contracts of the youth. We find no major change in the role played by the different fields in the probability of having a permanent or a full-time contract. The fields that enhance the most systematically the probability of a permanent or full-time contract, across countries and time, are Social Sciences, Business and Law; and Engineering, Manufacturing and Construction. The field that leads the most systematically to a temporary or part-time contract (see the rows for negative statistically significant signs) is Humanities, Languages and Arts.

[Table 3 and Table 4 about here] 
On the one hand, the field of Health and Welfare is the one increasing the most the probability of employment (Table 1), but it is also among the fields increasing the most the probability of temporary contracts and the probability of part-time agreements. Moreover, graduating from Social Sciences, Business and Law does not play any statistically significant advantage to get an employment but it does improve significantly the chances of having a full-time and permanent contract.

\subsection{Hypothesis 4 - The nature of contracts at the beginning of the career of a young graduate is affected by the work experience acquired during studies}

This specific hypothesis was tested using model (2) and the results from its estimation are synthesized in Table 2 (columns 2 and 3). We find that, ceteris paribus, the dummy variable workedu plays a statistically significant positive role on the probability of having a permanent contract in Bulgaria, Greece, Poland and Portugal, but a negative role in Belgium (column 2). With regard to the probability of working full-time (vs. part-time), it has a positive and significant effect only in one country, namely Greece. In all other countries its effect is statistically non-significant (column 3).

After replacing the dummy variable by the categorical WORKEDUC, we find that the categories of work during studies that play a positive and significant role on the probability of having a permanent contract are category 2 ("work while studying but outside educational programmes") and category 6 ("the combination of work outside the curriculum and during an interruption of studies). Moreover, the category of work during studies that tends to affect positively and significantly the probability of working full-time is category 1 ("work as part of educational programmes"). On the other hand, the category that tends to affect it in a negative way is category 2 ("work while studying but outside educational programmes"). These results may reflect continuity between the nature of the work contracts during studies (according to the category of work) and the current status. While an extra-curriculum job during full-time studies (category 2) can only be taken parttime, nothing hinders it from being permanent. On the other hand, a curriculum- 
based work experience (category 1 ) is often requested to be full-time during a temporary period to fit the degree programme.

\section{Conclusions}

This paper aimed at providing a first insight into the role played by the field of higher education degrees and the acquisition of a work experience during studies on the employability of the cohort of the new ET2020 Benchmark on graduates' employability. The analysis made use of the same data source and sample specifications as the benchmark indicator, namely the core LFS annual data from 2004 to 2010, to which the ad-hoc module of LFS 2009 was added. The results are reported in the frame of four hypotheses defined according to the assumptions and expectations of the European Commission on how education and training institutions can contribute to the employability of young graduates.

We used a probit approach, in which the dichotomous outcome was defined in three different ways for the 20-34 years old, who graduated 1 to 3 years before and not currently enrolled in any further education or training activity: first, as the probability of being employed; then, for those employed, as the probability of having a permanent contract (vs. temporary) and the probability of working full-time (vs. part-time). In the first model, the controls included the age, age squared, gender, time since graduation and the field of the degree, controlling for year and regional fixed effects. This model was run by country for two time periods (the pre-crisis and the crisis period). In the second model, we added to the previous one a control for the work during studies, using the WORKEDUC variable of the ad-hoc module of the LFS 2009.

Overall, when considering the impacts on the largest number of countries across time periods, we find that our analysis validates the four hypotheses. We find that the likelihood of employment is significantly affected by the field of the degree (Hypothesis 1). Still, the significant fields vary across countries within and across time periods (i.e. pre-crisis and crisis period). Interestingly, the only degree field that acts as a significant factor across countries and time is Health and Welfare, 
ceteris paribus. This constant effect reveals a lasting shortage of skills in that field that should be addressed by education and training institutions.

In terms of type of contracts, the probability of having a permanent and fulltime job is higher in the fields of Social Sciences, Business and Law; and Engineering, Manufacturing and Construction, which embed mainly applied (technical) degrees (Hypothesis 3).

Globally, the results from our analysis also confirm the comparative advantage played by a work experience during studies in the probability of employment of young graduates (Hypothesis 2). However, we find a potential inertia in the type of contracts earned by graduates that worked during their studies in the three years following the completion of their degree (Hypothesis 4). For instance, having worked as part of the curriculum increases the chances of having a full-time and temporary contract in the three years after graduation, while having worked outside the curriculum increases the chances of having a part-time and permanent contract. Because the type of work experience acquired during a tertiary degree will influence the nature of the contract after graduation, these results should be taken into consideration by decision makers, both at the educational level and at the labour market level.

It is important to highlight that these results are all conditioned by the nature of our data and by our model specifications. The comparability constraints underlying the Eurostat surveys used in this paper constitute both a strength and a limitation. While they enable robust international and time comparisons, they hinder from defining models that capture more specific and detailed individual characteristics. As a consequence, our results should be taken with caution because they do not account for individual motivations, family background, intrinsic abilities, etc., which could each potentially affect the probability of employment and the probability of having a permanent and/or full-time contract. Finally, this paper did not report any findings on the quality of the employment of young graduates. Rather, it simply looked at the type of contracts young graduates tend to get in the three years following their graduation as a proxy of smooth transitions from 
education to work. Further research is now needed to understand the determinants to skills (mis)match and work quality.

\section{References}

Arjona Perez, E., Garrouste, C. and Kozovska, K. (2010a), "Towards a benchmark on the contribution of Education and Training to Employability: a discussion note", JRC Scientific and Technical Reports EUR 24147 EN, Joint Research Center, Ispra.

Arjona Perez, E., Garrouste, C. and Kozovska, K. (2010b), "Towards a benchmark on the contribution of Education and Training to Employability: In-depth analysis of key issues", JRC Scientific and Technical Reports EUR 24624 EN, Joint Research Center, Ispra.

Boateng, S. K., Garrouste, C. and Jouhette, S. (2011), "Measuring Transition from School to Work in the EU: Role of the data source", Conference paper presented at the Conference Catch the Train: Skills, Education and Jobs, Brussels, June 2021, 2011, available at: http://crell.jrc.ec.europa.eu/download/Boeteng1.pdf (accessed 25 March 2013).

Carnevale, A. P., Cheah, B. and Strohl, J. (2012), "College Majors, Unemployment and Earnings: Not all college degrees are created equal", Georgetown University Center on Education and the Workforce, Washington, DC, June.

Cedefop (2008), Terminology of European Education and Training Policy, European Union Publications Office, Luxemburg.

Cedefop (2012). "Future skills supply and demand in Europe: Forecast 2012", Research Paper No.26, Cedefop, Thessaloniki.

Crebert, G., Bates, M., Bell, B., Patrick, C.-J. and Cragnolini, V. (2004), "Developing generic skills at university, during work placement and in employment: graduates' perceptions", Higher Education Research \& Development, Vol.23 No.2, pp. 147-65.

Curtis, S. and Shani, N. (2002), "The effect of taking paid employment during termtime on students' academic studies", Journal of Further and Higher Education, Vol. 26 No.2, pp. 129-38. 
De Grip, A., van Loo, J. and Sanders, J. (2004), "The Industry Employability Index: Taking Account of Supply and Demand Characteristics", International Labour Review, Vol. 143 No.3, pp. 211-33.

Dustmann, C., Micklewright, J., Rajah, N. and Smith, S. (1996), "Earning and learning: educational policy and the growth of part-time work by full-time pupils", Fiscal Studies, Vol. 17 No.1, pp. 79-105.

Eckstein, Z. and Wolpin, K. I. (1995), "Duration to first job and the return to schooling: Estimates from a search-matching model", The Review of Economic Studies, Vol. 62 No.2, pp. 263-86.

Ehrenberg, R.G. and Sherman, D.R. (1985), "Employment while in College, Academic Achievemnt and Post-college Outcomes: A summary of results", NBER Working paper No. 1742, National Bureau of Economic Research, Cambridge, MA, October.

European Commission (2011), "Commission Staff Working Paper on the development of benchmarks on education and training for employability and on learning mobility: SEC(2011), 670 final", European Commission, Brussels, May.

European Council (2012), "Council conclusions of 11 May 2012 on the employability of graduates from education and training: 2012/C 169/04", European Union, Luxembourg, June.

Garrouste, C. (2011), "Towards a Benchmark on the Contribution of Education and Training to Employability: Methodological Note", JRC Scientific and Technical Reports EUR 24616 EN.

Garrouste, C. and Rodrigues, M. (2012), "The employability of young graduates in Europe: Analysis of the ET2020 benchmark", JRC Scientific and Technical Reports EUR 25624 EN, Joint Research Center, Ispra.

Harvey, L., Geall, V. and Moon, S. (1998), Work Experience: Expanding Opportunities for Undergraduates, Centre for Research into Quality, Birmingham.

Kelly, E., O'Connell, P.J. and Smyth, E. (2010), "The economic returns to field of study and competencies among higher education graduates in Ireland", Economics of Education Review, Vol. 29 No. 4, pp. 650-7. 
Korpi, T., De Graaf, P., Hendrickx, J. and Layte, R. (2003), "Vocational training and career employment precariousness in Great Britain, the Netherlands and Sweden", Acta Sociologica, Vol. 46 No.1, pp. 17-30.

Leonard, M. (1995), "Labouring to learn: students' debt and term time employment in Belfast", Higher Education Quarterly, Vol. 49 No.3, pp. 229-47.

Lindsay, R. O., \& Paton-Saltzburg, R. (1993), The effects of played employment on academic performance of full-time students in higher education, Oxford Brookes University, Oxford.

Marshall, A.E. (1985), "Employment Roles of College Graduates: How Important Are They? ", Journal of Employment Counseling, Vol. 22 No.4, pp.136-43.

McQuaid, R. and Lindsay, C. (2005), "The Concept of Employability", Urban Studies, Vol. 42 No.2, pp. 197-219.

McVicar, D. and McKee, B. (2002), "Part-Time Work During Post-Compulsory Education And Examination Performance: Help Or Hindrance? ", Scottish Journal of Political Economy, Vol. 49 No.4, pp. 393-406.

Neill, N., Mulholland, G., Ross, V. and Leckey, J. (2004), "The influence of part-time work on student placement", Journal of Further and Higher Education, Vol. 28 No.2, pp. 123-37.

OECD (2000), Thematic Review of the Transition from Initial Education to Working Life, OECD Publications, Paris.

Robst, J. (2007), "Education and job match: the relatedness of college major and work", Economics of Education, Vol. 26, pp.397-407.

Schmelzer, P. (2011), "Unemployment in early career in the UK A trap or a stepping stone? ", Acta Sociologica, Vol. 54 No.3, pp. 251-65.

Shah, A., Pell, K. and Brooke, P. (2004), "Beyond First Destinations: Graduate Employability Survey", Active Learning in higher Education, Vol.5 No.1, pp. 926.

Watts, A. G. (2006), "Career development learning and employability", in Yorke, M. (Ed.), Learning and Employability Series 2, The Higher Education Academy, York. 
Watts, C. and Pickering, A. (2000), "Pay as you learn: student employment and academic progress", Education+ Training, Vol. 42 No.3, pp. 129-35.

Wolbers, M. H. (2007), "Patterns of Labour Market Entry A Comparative Perspective on School-to-Work Transitions in 11 European Countries", Acta sociologica, Vol. 50 No.3, pp. 189-210.

Wooldridge, J. M. (2010), Econometric Analysis of Cross Section and Panel Data, The MIT Press, Boston, MA. 
Table 1 - Summative table of the estimated contribution of each degree field on the probability of being employed, by time period and by country, ceteris paribus Model (1)

\begin{tabular}{|c|c|c|c|c|c|c|}
\hline & \multicolumn{3}{|c|}{ Pre-crisis (2004-2007) } & \multicolumn{3}{|c|}{ Crisis (2008-2010) } \\
\hline & + & - & n.s. & + & - & n.s. \\
\hline Agriculture and veterinary & None & AT, PL, SI & All other countries & LT & GR, IT, MT & All other countries \\
\hline Computer Science & EE, IT, PL, PT, SK & None & All other countries & $\mathrm{BE}, \mathrm{CZ}, \mathrm{ES}, \underline{\mathrm{IT}}$ & GR & All other countries \\
\hline Computer Use & None & HU, UK & All other countries & PL & IE & All other countries \\
\hline $\begin{array}{l}\text { Engineering, manufacturing } \\
\text { and construction }\end{array}$ & $\begin{array}{l}\text { AT, BG, ES, GR, IT, PL, PT, } \\
\text { SI, SK, UK }\end{array}$ & None & All other countries & $\mathrm{FR}, \underline{\mathrm{IT}}$ & LT & All other countries \\
\hline Foreign languages & HU, PL, RO & $\mathrm{BE}, \underline{\mathrm{FR}}, \mathrm{MT}, \mathrm{NL}$ & All other countries & None & $\mathrm{DK}, \underline{\mathrm{FR}}, \mathrm{PT}$ & All other countries \\
\hline General programmes & None & None & All countries & None & UK & All other countries \\
\hline Health and welfare & $\begin{array}{l}\text { BE, } \underline{\mathrm{DK}}, \underline{\mathrm{FR}}, \underline{\mathrm{HU}}, \underline{\mathrm{IT}}, \mathrm{MT}, \\
\mathrm{PT}, \underline{\mathrm{RO}}, \underline{\mathrm{SE}}, \mathrm{SI}, \underline{\mathrm{UK}}\end{array}$ & $\mathrm{CZ}, \mathrm{GR}$ & All other countries & $\begin{array}{l}\text { AT, } \underline{\mathrm{BE}}, \mathrm{BG}, \underline{\mathrm{DK}}, \mathrm{FI}, \\
\underline{\mathrm{FR}}, \underline{\mathrm{HU}}, \underline{\underline{\mathrm{T}}}, \mathrm{NL}, \mathrm{PL}, \underline{\mathrm{PT}}, \\
\underline{\mathrm{RO}}, \underline{\underline{\mathrm{EE}}}, \underline{\underline{\mathrm{UK}}}\end{array}$ & None & All other countries \\
\hline $\begin{array}{l}\text { Humanities, languages and } \\
\text { arts }\end{array}$ & None & $\begin{array}{l}\underline{\mathrm{AT}}, \underline{\mathrm{BE}}, \underline{\mathrm{CY}}, \underline{\mathrm{DK}}, \underline{\mathrm{ES}}, \underline{\mathrm{FI}}, \underline{\mathrm{FR}}, \\
\underline{\mathrm{GR}}, \underline{\mathrm{HU}}, \underline{\underline{\mathrm{IT}}}, \mathrm{PL}, \mathrm{PT}, \underline{\mathrm{SE}}, \mathrm{SI}, \mathrm{UK}\end{array}$ & All other countries & None & $\begin{array}{l}\underline{\mathrm{AT}}, \underline{\mathrm{BE}}, \underline{\mathrm{CY}}, \mathrm{CZ}, \mathrm{DE}, \underline{\mathrm{DK}}, \\
\underline{\mathrm{ES}}, \underline{\mathrm{FI}}, \underline{\mathrm{FR}}, \underline{\mathrm{GR}}, \underline{\mathrm{HU}}, \mathrm{IE}, \\
\underline{\mathrm{IT}}, \underline{\mathrm{MT}}, \underline{\mathrm{SE}}\end{array}$ & All other countries \\
\hline Life sciences & None & CZ, DK, PL & All other countries & None & None & All countries \\
\hline Mathematics and statistics & $\mathrm{PT}, \mathrm{UK}$ & $\mathrm{CY}, \mathrm{LV}$ & All other countries & None & SI & All other countries \\
\hline Physical science & UK & GR, PT, SI, SK & All other countries & ES, LT, SI & AT, DK, $\underline{\mathrm{SK}}$ & All other countries \\
\hline $\begin{array}{l}\text { Science, mathematics and } \\
\text { computing }\end{array}$ & None & PL, SE & All other countries & None & EE, SE & All other countries \\
\hline Services & CZ, DE, GR, IT, $\underline{\text { SE, UK }}$ & None & All other countries & GR, $\underline{\mathrm{SE}}$ & None & All other countries \\
\hline $\begin{array}{l}\text { Social sciences, business and } \\
\text { law }\end{array}$ & $\mathrm{CZ}, \mathrm{HU}$ & $\underline{\mathrm{FR}}, \underline{\mathrm{IT}}, \mathrm{MT}, \underline{\mathrm{PT}}, \mathrm{SK}, \mathrm{UK}$ & All other countries & $\mathrm{CY}, \mathrm{SE}, \mathrm{SK}$ & $\underline{\mathrm{FR}}, \underline{\mathrm{IT}}, \underline{\mathrm{PT}}$ & All other countries \\
\hline $\begin{array}{l}\text { Teacher training and } \\
\text { education science }\end{array}$ & DK, $\underline{\mathrm{FR}}, \underline{\mathrm{IE}}, \underline{\mathrm{IT}}, \mathrm{MT}$ & $\mathrm{CZ}, \mathrm{GR}, \underline{\mathrm{HU}}, \mathrm{PT}$ & All other countries & $\underline{\mathrm{FR}}, \mathrm{GR}, \underline{\mathrm{IE}}, \underline{\mathrm{IT}}, \mathrm{LV}$ & $\underline{\mathrm{HU}}, \mathrm{SK}$ & All other countries \\
\hline
\end{tabular}

Source: From authors' estimations of Model (1) using the core LFS data for 2004-2010.

Notes:

' + ' and '-' respectively designate a positive and negative coefficient that is statistically significant at least at the $\mathrm{p}<0.05$ level.

'n.s.' means that the coefficient is statistically non-significant (its sign is therefore not reported).

AT=Austria; BE=Belgium; CZ=Czech Republic; DE=Germany; DK=Denmark; EE=Estonia; ES=Spain; FI=Finland; FR=France; GR=Greece; HU=Hungary; IE=Ireland; IS=Iceland; IT=Italy; LT=Lithuania;

LU=Luxemburg; LV=Latvia; MT=Malta; NL=Netherlands; PL=Poland; PT=Portugal; RO=Romania; SE=Sweden; SI=Slovenia; SK=Slovakia; UK=United Kingdom.

Underscored countries are countries which revealed the same sign and significance of coefficient over time for a given field of degree.

The detailed estimation results for each model and by country are available upon request. 
Table 2 - Summative table of the estimated contribution of work during studies on the probability of being employed, of having a permanent contract and of working full-time, ceteris paribus - Model (2)

\begin{tabular}{|c|c|c|c|c|c|c|c|c|}
\hline \multicolumn{3}{|c|}{ Employed } & \multicolumn{3}{|c|}{ Permanent } & \multicolumn{3}{|c|}{ Full-time } \\
\hline+ & - & n.s. & + & - & n.s. & + & - & n.s. \\
\hline
\end{tabular}

$\mathbf{1}^{\text {st }}$ model specification: Dummy variable workedu ( $=1$ if worked during studies; $=0$ otherwise)

\begin{tabular}{l||l|l|l|l||l|l|l}
\hline workedu & $\begin{array}{l}\text { BG, }, \text { CZ, GR, IE, NL, PL, } \\
\text { RO, IT }\end{array}$ & None & $\begin{array}{l}\text { All other } \\
\text { countries }\end{array}$ & $\begin{array}{l}\text { BG, GR, PL, } \\
\text { PT }\end{array}$ & BE & $\begin{array}{l}\text { All other } \\
\text { countries }\end{array}$ & $\begin{array}{l}\text { All other } \\
\text { countries }\end{array}$ \\
\hline \hline
\end{tabular}

$2^{\text {nd }}$ model specification: Categorical variable WORKEDUC (Reference category: No work experience at all)

\begin{tabular}{|c|c|c|c|c|c|c|c|c|c|}
\hline 1. Work (only) as part of educational programme & IE & None & $\begin{array}{l}\text { All other } \\
\text { countries }\end{array}$ & $\underline{\mathrm{NL}}$ & $\mathrm{BE}$ & $\begin{array}{l}\text { All other } \\
\text { countries }\end{array}$ & $\begin{array}{l}\text { GR, } \\
\text { NL }\end{array}$ & AT & $\begin{array}{l}\text { All other } \\
\text { countries }\end{array}$ \\
\hline $\begin{array}{l}\text { 2. Work while studying but outside educational } \\
\text { programmes }\end{array}$ & $\begin{array}{l}\text { DK, GR, IE, IT, LT, NL, } \\
\text { PT, RO }\end{array}$ & None & $\begin{array}{l}\text { All other } \\
\text { countries }\end{array}$ & $\mathrm{BG}, \mathrm{HU}, \underline{\mathrm{PL}}$ & None & $\begin{array}{l}\text { All other } \\
\text { countries }\end{array}$ & $\underline{\mathrm{PL}}$ & $\begin{array}{l}\text { AT, HU, } \\
\text { IT }\end{array}$ & $\begin{array}{l}\text { All other } \\
\text { countries }\end{array}$ \\
\hline 3. Work (only) during an interruption of studies & None & FR & $\begin{array}{l}\text { All other } \\
\text { countries }\end{array}$ & None & ES & $\begin{array}{l}\text { All other } \\
\text { countries }\end{array}$ & None & PT & $\begin{array}{l}\text { All other } \\
\text { countries }\end{array}$ \\
\hline 4. Work as combination of 1 and 2 & $\underline{\mathrm{BG}}, \underline{\mathrm{GR}}, \mathrm{IT}$ & None & $\begin{array}{l}\text { All other } \\
\text { countries }\end{array}$ & $\underline{B G}, \underline{G R}$ & None & $\begin{array}{l}\text { All other } \\
\text { countries }\end{array}$ & $\underline{\mathrm{GR}}$ & AT, PT & $\begin{array}{l}\text { All other } \\
\text { countries }\end{array}$ \\
\hline 5. Work as combination of 1 and 3 & None & None & All countries & None & None & All countries & None & AT, IT & $\begin{array}{l}\text { All other } \\
\text { countries }\end{array}$ \\
\hline 6. Work as combination of 2 and 3 & $\underline{\mathrm{PL}}$ & AT & $\begin{array}{l}\text { All other } \\
\text { countries }\end{array}$ & $\underline{\mathrm{PL}}, \mathrm{PT}$ & ES & $\begin{array}{l}\text { All other } \\
\text { countries }\end{array}$ & None & AT & $\begin{array}{l}\text { All other } \\
\text { countries }\end{array}$ \\
\hline 7. Work as combination of 1,2 and 3 & None & None & All countries & None & None & All countries & None & None & All countries \\
\hline
\end{tabular}

Source: From authors' estimations of Model (2) using the ad-hoc module of the LFS 2009.

Source:

' + ' and '-' respectively designate a positive and negative coefficient that is statistically significant at least at the $p<0.05$ level.

'n.s.' means that the coefficient is statistically non-significant (its sign is therefore not reported).

AT=Austria; BE=Belgium; CZ=Czech Republic; DE=Germany; DK=Denmark; EE=Estonia; ES=Spain; FI=Finland; FR=France; GR=Greece; HU=Hungary; IE=Ireland; IS=Iceland; IT=Italy; LT=Lithuania;

LU=Luxemburg; LV=Latvia; MT=Malta; NL=Netherlands; PL=Poland; PT=Portugal; RO=Romania; SE=Sweden; SI=Slovenia; SK=Slovakia; UK=United Kingdom.

Underscored countries are countries which revealed the same sign and significance of coefficient across models for a given field of degree.

* The sample is reduced to those employed at the time of the study.

The detailed estimation results for each model and by country are available upon request. 
Table 3 - Summative table of the estimated contribution of the field of the degree on the probability of having a permanent contract, by time period, ceteris paribus Model (1)

\begin{tabular}{|c|c|c|c|c|c|c|}
\hline & \multicolumn{3}{|c|}{ Pre-crisis (2004-2007) } & \multicolumn{3}{|c|}{ Crisis (2008-2010) } \\
\hline & + & - & n.s. & + & - & n.s. \\
\hline Agriculture and veterinary & UK & PL, PT, SE, SI, SK & All other countries & None & NL & All other countries \\
\hline Computer Science & $\underline{\mathrm{BE}}, \mathrm{CZ}, \underline{\mathrm{FR}}, \underline{\mathrm{NL}}, \mathrm{RO}$ & None & All other countries & $\underline{\mathrm{BE}}, \mathrm{DK}, \mathrm{FI}, \underline{\mathrm{FR}}, \underline{\mathrm{NL}}, \mathrm{SE}$ & None & All other countries \\
\hline Computer Use & $\underline{B E}$ & None & All other countries & $\underline{\mathrm{BE}}$ & None & All other countries \\
\hline $\begin{array}{l}\text { Engineering, manufacturing } \\
\text { and construction }\end{array}$ & $\begin{array}{l}\underline{\mathrm{AT}}, \underline{\mathrm{BE}}, \underline{\mathrm{CY}}, \underline{\mathrm{DE}}, \underline{\mathrm{FI}}, \underline{\mathrm{GR}}, \underline{\mathrm{HU}}, \underline{\mathrm{SE}}, \mathrm{SI}, \underline{\mathrm{UK}}\end{array}$ & LT, LV, NL, PL & All other countries & $\begin{array}{l}\underline{\mathrm{AT}}, \underline{\mathrm{BE}}, \underline{\mathrm{DE}}, \mathrm{DK}, \underline{\mathrm{FI}}, \underline{\mathrm{GR}}, \\
\underline{\mathrm{HU}}\end{array}$ & None & All other countries \\
\hline Foreign languages & None & $\underline{\mathrm{CY}}, \mathrm{FI}, \mathrm{PT}$ & All other countries & None & $\mathrm{AT}, \underline{\mathrm{CY}}, \mathrm{DE}, \mathrm{UK}$ & All other countries \\
\hline General programmes & None & None & All countries & None & $\mathrm{HU}$ & All other countries \\
\hline Health and welfare & $\underline{\mathrm{BE}}, \mathrm{BG}, \underline{\mathrm{IT}}, \mathrm{PT}, \mathrm{SK}, \mathrm{UK}$ & $\frac{\mathrm{AT}}{\mathrm{PL}}, \underline{\mathrm{CY}}, \underline{\mathrm{SE}}, \underline{\mathrm{DE}}, \underline{\mathrm{ES}}, \mathrm{FI}, \underline{\mathrm{GR}}$, & All other countries & $\underline{\mathrm{BE}}, \underline{\mathrm{IT}}$ & $\underline{\mathrm{AT}}, \underline{\mathrm{CY}}, \underline{\mathrm{DE}}, \underline{\mathrm{ES}}, \underline{\mathrm{GR}}, \underline{\mathrm{SE}}$ & All other countries \\
\hline Humanities, languages and arts & None & $\begin{array}{l}\mathrm{AT}, \underline{\mathrm{BE}}, \mathrm{BG}, \underline{\mathrm{CY}}, \mathrm{DE}, \mathrm{DK}, \\
\mathrm{FI}, \underline{\mathrm{FR}}, \underline{\mathrm{GR}}, \mathrm{IE}, \underline{\mathrm{IT}}, \mathrm{PL}, \underline{\mathrm{RO}}, \\
\underline{\text { SE}}, \mathrm{SI}\end{array}$ & All other countries & None & $\begin{array}{l}\text { BE, CY, DK, ES, FR, GR, } \\
\underline{\mathrm{IT}}, \underline{\mathrm{LT}}, \underline{\mathrm{RO}}, \underline{\mathrm{SE}}, \underline{\mathrm{UK}}\end{array}$ & All other countries \\
\hline Life sciences & AT & 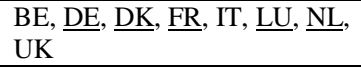 & All other countries & None & $\underline{\mathrm{DE}}, \underline{\mathrm{DK}}, \underline{\mathrm{FR}}, \underline{\mathrm{LU}}, \underline{\mathrm{NL}}, \mathrm{PT}$, & All other countries \\
\hline Mathematics and statistics & IT & $\underline{\mathrm{AT}}, \mathrm{GR}, \mathrm{SI}$ & All other countries & None & $\underline{\mathrm{AT}}, \mathrm{BE}, \mathrm{LU}, \mathrm{SE}$ & All other countries \\
\hline Physical science & None & $\underline{\mathrm{BE}}, \mathrm{DE}, \mathrm{ES}, \underline{\mathrm{FI}}, \mathrm{PL}, \underline{\mathrm{PT}}, \mathrm{UK}$ & All other countries & None & $\frac{\mathrm{BE}}{\mathrm{RO}}, \mathrm{DK}, \mathrm{EE}, \underline{\mathrm{FI}}, \mathrm{IE}, \underline{\mathrm{PT}}$, & All other countries \\
\hline $\begin{array}{l}\text { Science, mathematics and } \\
\text { computing }\end{array}$ & MT, UK & $\mathrm{IE}, \underline{\mathrm{SE}}$ & All other countries & None & SE, SK & All other countries \\
\hline Services & $\begin{array}{l}\text { AT, DK, FI, GR, LT, RO, SE, } \\
\text { UK }\end{array}$ & LV & All other countries & CY, DE, ES, GR, IE, $\underline{\mathrm{SE}}$ & FR & All other countries \\
\hline Social sciences, business and law & $\begin{array}{l}\text { AT, }, \underline{\mathrm{BE}}, \underline{\mathrm{CY}}, \underline{\mathrm{CZ}}, \mathrm{DE}, \mathrm{DK}, \underline{\mathrm{ES}}, \\
\mathrm{FI}, \underline{\mathrm{GR}}, \mathrm{LU}, \underline{\mathrm{PL}}, \mathrm{PT}, \underline{\mathrm{RO}}, \mathrm{SI}\end{array}$ & MT & All other countries & $\begin{array}{l}\frac{\mathrm{AT}}{\mathrm{DK}}, \underline{\mathrm{BE}}, \underline{\mathrm{CY}}, \underline{\mathrm{CZ}}, \underline{\mathrm{DE}}, \\
\underline{\mathrm{RO}}, \underline{\mathrm{SK}}\end{array}$ & MT & All other countries \\
\hline $\begin{array}{l}\text { Teacher training and education } \\
\text { science }\end{array}$ & DK, SE & $\frac{\mathrm{AT}}{\mathrm{RO}}, \underline{\mathrm{BE}}, \underline{\mathrm{DE}}, \underline{\mathrm{FI}}, \mathrm{GR}, \underline{\mathrm{HU}}, \underline{\mathrm{PT}}$, & All other countries & None & $\begin{array}{l}\text { AT, BE, CY, DE, FI, } \underline{\mathrm{HU}}, \\
\mathrm{IE}, \mathrm{PL}, \underline{\mathrm{PT}}, \underline{\mathrm{SI}}, \mathrm{SK}, \mathrm{UK}\end{array}$ & All other countries \\
\hline
\end{tabular}
Source: From authors' estimations of Model (1) using the core LFS data for $2004-2010$

Source:

' + ' and '-' respectively designate a positive and negative coefficient that is statistically significant at least at the $\mathrm{p}<0.05$ level.

'n.s.' means that the coefficient is statistically non-significant (its sign is therefore not reported).

LU=Luxemburg; LV=Latvia; MT=Malta; NL=Netherlands; PL=Poland; PT=Portugal; RO=Romania; SE=Sweden; SI=Slovenia; SK=Slovakia; UK=United Kingdom.

Underscored countries are countries which revealed the same sign and significance of coefficient over time for a given field of degree. The detailed estimation results for each model and by country are available 
Table 4 - Summative table of the estimated contribution of the field of the degree on the probability of working full-time, by time period, ceteris paribus - Model (1)

\begin{tabular}{|c|c|c|c|c|c|c|}
\hline & \multicolumn{3}{|c|}{ Pre-crisis (2004-2007) } & \multicolumn{3}{|c|}{ Crisis (2008-2010) } \\
\hline & + & - & n.s. & + & - & n.s. \\
\hline Agriculture and veterinary & DK, GR, NL, PT, UK & $\underline{\mathrm{LT}}, \mathrm{SK}$ & All other countries & ES & $\mathrm{DE}, \underline{\mathrm{LT}}, \mathrm{NL}$ & All other countries \\
\hline Computer Science & $\begin{array}{l}\text { BE, DE, ES, FR, IT, NL, } \\
\text { RO }\end{array}$ & None & All other countries & $\mathrm{DK}, \underline{\mathrm{ES}}, \underline{\mathrm{FR}}, \mathrm{SE}$ & LT & All other countries \\
\hline Computer Use & DK & IE, LV & All other countries & None & None & All countries \\
\hline $\begin{array}{l}\text { Engineering, manufacturing } \\
\text { and construction }\end{array}$ & $\begin{array}{l}\text { AT, } \underline{\mathrm{BE}}, \underline{\mathrm{CY}}, \underline{\mathrm{DE}}, \underline{\mathrm{ES}}, \underline{\mathrm{FI}}, \\
\mathrm{FR} \\
\underline{\mathrm{PR}}, \underline{\mathrm{GE}}, \underline{\mathrm{SI}}, \underline{\mathrm{SK}}, \underline{\mathrm{LT}}, \underline{\mathrm{UK}}\end{array}$ & None & All other countries & $\begin{array}{l}\text { AT, } \underline{\mathrm{BE}}, \underline{\mathrm{CY}}, \underline{\mathrm{DE}}, \underline{\mathrm{DK}}, \\
\mathrm{ES}\end{array}$ & None & All other countries \\
\hline Foreign languages & RO & $\underline{\mathrm{FR}}, \mathrm{GR}, \mathrm{IE}, \underline{\mathrm{PL}}, \mathrm{PT}, \mathrm{SE}, \mathrm{SK}$ & All other countries & None & $\mathrm{CY}, \mathrm{DE}, \mathrm{FI}, \underline{\mathrm{FR}}, \mathrm{IT}, \underline{\mathrm{PL}}$ & All other countries \\
\hline General programmes & None & None & All countries & None & ES & All other countries \\
\hline Health and welfare & $\mathrm{CY}, \mathrm{GR}, \mathrm{SK}$ & BE, DE, DK, LU, NL, SE & All other countries & FI, IT & $\underline{\mathrm{BE}}, \underline{\mathrm{DK}}, \underline{\mathrm{NL}}, \underline{\mathrm{SE}}$ & All other countries \\
\hline Humanities, languages and arts & None & 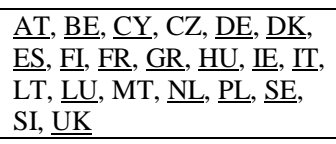 & All other countries & None & $\begin{array}{l}\underline{\mathrm{AT}}, \underline{\mathrm{BE}}, \underline{\mathrm{CY}}, \underline{\mathrm{DE}}, \underline{\mathrm{DK}}, \\
\underline{\mathrm{EE}}, \underline{\mathrm{ES}}, \underline{\mathrm{FI}}, \underline{\mathrm{FR}}, \underline{\mathrm{GR}}, \\
\underline{\mathrm{HU}}, \underline{\mathrm{IE}}, \underline{\mathrm{IT}}, \underline{\mathrm{LU}}, \underline{\mathrm{UK}},\end{array}$ & All other countries \\
\hline Life sciences & DK, NL & $\mathrm{DE}, \mathrm{EE}$ & All other countries & BE, SE, UK & LU & All other countries \\
\hline Mathematics and statistics & None & $\underline{\mathrm{GR}}, \mathrm{RO}$ & All other countries & None & $\underline{\mathrm{GR}}, \mathrm{IE}, \mathrm{PL}, \mathrm{SI}$ & All other countries \\
\hline Physical science & None & $\mathrm{CY}, \mathrm{DE}, \mathrm{PT}$ & All other countries & None & DK, GR & All other countries \\
\hline $\begin{array}{l}\text { Science, mathematics and } \\
\text { computing }\end{array}$ & None & SK & All other countries & IT & $\mathrm{CY}, \mathrm{RO}$ & All other countries \\
\hline Services & $\underline{\mathrm{DE}}, \mathrm{DK}, \mathrm{NL}, \underline{\mathrm{SE}}$ & $\underline{\mathrm{IT}}, \mathrm{UK}$ & All other countries & $\underline{\mathrm{DE}}, \underline{\mathrm{SE}}$ & $\mathrm{BE}, \mathrm{FR}, \underline{\mathrm{IT}}$ & All other countries \\
\hline $\begin{array}{l}\text { Social sciences, business and } \\
\text { law }\end{array}$ & $\begin{array}{l}\mathrm{AT}, \underline{\mathrm{BE}}, \underline{\mathrm{CY}}, \underline{\mathrm{CZ}}, \underline{\mathrm{DE}}, \frac{\mathrm{DK}}{\mathrm{E}}, \\
\mathrm{EE}, \mathrm{FR}, \mathrm{GR}, \mathrm{HU}, \mathrm{IT}, \mathrm{LT}, \\
\underline{\mathrm{LU}}, \underline{\mathrm{NL}}, \underline{\mathrm{PL}}, \underline{\mathrm{PT}}, \underline{\mathrm{SE}}, \mathrm{SI}, \mathrm{UK}\end{array}$ & None & All other countries & $\begin{array}{l}\mathrm{AT}, \underline{\mathrm{BE}}, \underline{\mathrm{CY}}, \underline{\mathrm{CZ}}, \underline{\mathrm{DE}}, \\
\underline{\mathrm{DK}}, \underline{\mathrm{GR}}, \underline{\mathrm{LT}}, \underline{\mathrm{LU}}, \underline{\mathrm{NL}}, \\
\underline{\mathrm{PL}}, \underline{\mathrm{PT}}, \underline{\mathrm{SE}}, \underline{\mathrm{SK}}\end{array}$ & None & All other countries \\
\hline $\begin{array}{l}\text { Teacher training and education } \\
\text { science }\end{array}$ & BG, LV & $\begin{array}{l}\underline{\mathrm{AT}}, \underline{\mathrm{BE}}, \underline{\mathrm{CZ}}, \underline{\mathrm{DE}}, \mathrm{EE}, \underline{\mathrm{ES}}, \\
\mathrm{HU} \\
\underline{\mathrm{PT}}, \underline{\mathrm{SE}}, \underline{\mathrm{LI}}, \underline{\mathrm{SI}}, \underline{\mathrm{NL}}, \underline{\mathrm{PL}}\end{array}$ & All other countries & IE & 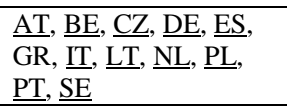 & All other countries \\
\hline
\end{tabular}

Source: From authors' estimations of Model (1) using the core LFS data for 2004-2010.

Notes: See notes of Table 3. 
Table A.1 Means (standard deviations) of selected variables, pooled estimated sample (Core LFS data 2004-2010 and ad-hoc module LFS 2009)

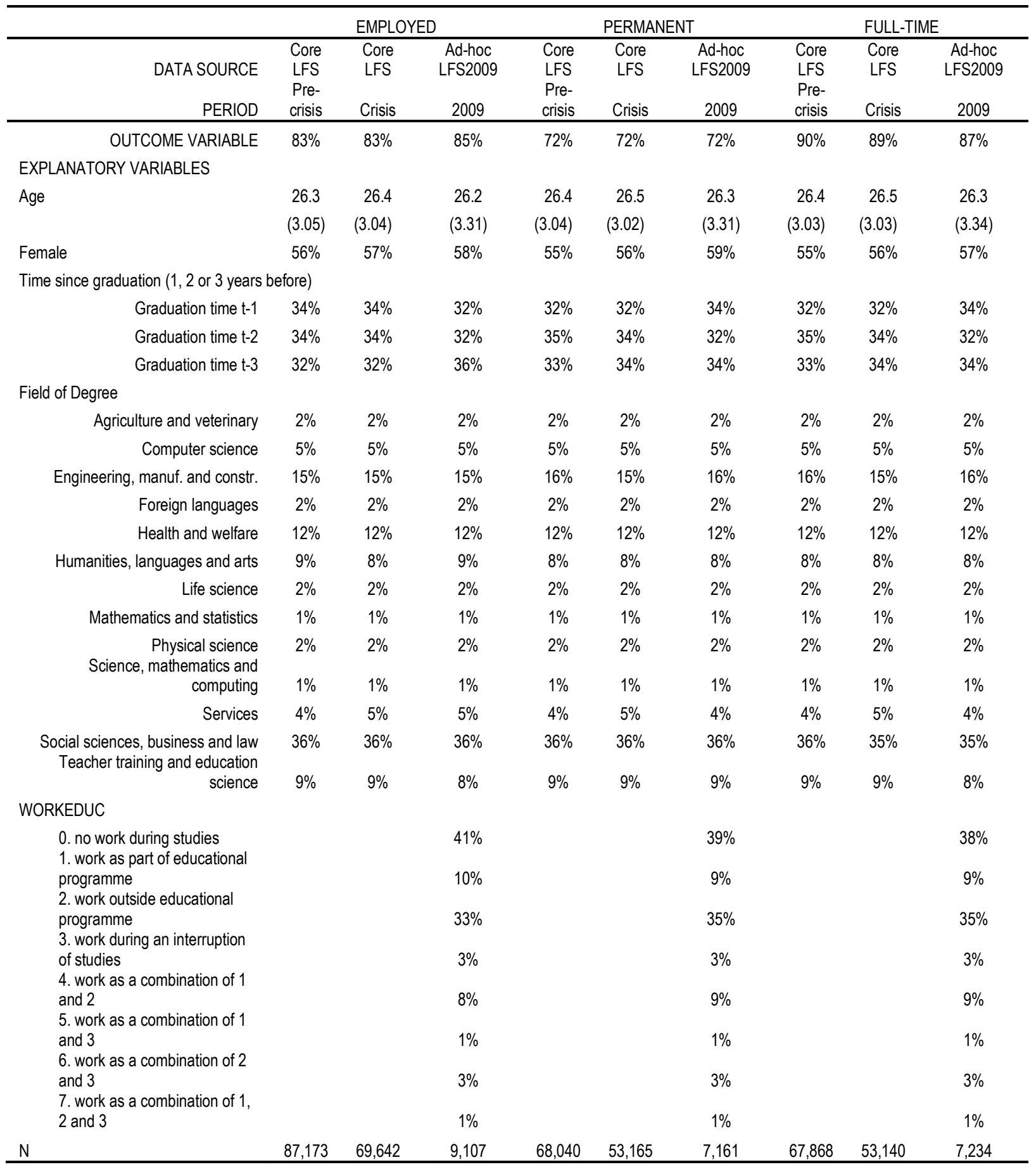

Note: The descriptive statistics refer to the mean values of estimated variables using the weighted pooled samples. Descriptive statistics at country level are available upon request. 
[1] The age bounds were selected in order to be aligned with other Europe 2020 targets. In particular, 20 years old is the lower bound of the headline target of the Europe 2020 strategy (20-64) and 34 is the upper bound of the ET 2020 benchmark on tertiary attainment (30-34). Only those graduating from ISCED levels 3-6 are considered in the benchmark indicator. The group of graduates with less than upper secondary education (ISCED 0-2 and ISCED 3C short) was excluded given that there is already a benchmark targeting the early school leavers from education and training aged 18-24 years old. Only those graduating one to three years before the reference year are included. The minimum of one year was chosen to avoid the possible impact of short unemployment periods which are common in the early months of transition. The maximum of three years was chosen as this was considered to be the time range within which educational attainment contributes the most to the probability of finding a job. Finally, individuals currently engaged in education were ignored because a current upgrade of skills could impact their probability of employment (For further details, see Garrouste, 2011 and Boateng et al., 2011). 